Review

\title{
Advanced oxidation processes for in-situ production of hydrogen peroxide/hydroxyl radical for textile wastewater treatment: a review
}

\author{
Anam Asghar, Abdul Aziz Abdul Raman*, Wan Mohd Ashri Wan Daud
}

Chemical Engineering Department, Faculty of Engineering, University Malaya, 50603 Kuala Lumpur, Malaysia

A R T I C L E I N F O

Article history:

Received 31 May 2014

Received in revised form

23 August 2014

Accepted 5 September 2014

Available online 16 September 2014

Keywords:

Hydrogen peroxide

Hydroxyl radicals

Fenton process

Textile wastewater

Advanced oxidation process

Sonolysis

\begin{abstract}
A B S T R A C T
Fenton Process, a type of Advanced Oxidation Processes is an efficient method for treating textile wastewaters. However, excessive use of hydrogen peroxide and catalyst has made this process economically non-feasible. Besides, industrial grade hydrogen peroxide costs $\$ 390-500$ per ton. One of the means to overcome this problem is the in-situ production of hydrogen peroxide. In this paper, a detailed review was conducted on the generation methods, degradation potential and optimum operating parameters for in-situ production of hydrogen peroxide/hydroxyl radicals. Additionally the scavenging aspect for hydroxyl radicals was also investigated. From this review, it can be concluded that hydroxyl radical is highly oxidative and non selective in nature and its in-situ production can be performed through application of catalyst, ozonation, photocatalysis, electro and microbial fuel cells. Furthermore, optimization of operating parameters can result in an increase in the yield of hydroxyl radicals/hydrogen peroxide. Sonolysis as an auxiliary tool has potential to induce synergetic effects in combination with Advanced Oxidation Processes to increase in-situ hydrogen peroxide production. However, the problem of the scavenging effect is an aspect that needs to be dealt with, as hydroxyl radicals are prone to deactivation by scavengers. Therefore based on the review, it is concluded that insitu production of hydrogen peroxide/hydroxyl radical for treating textile wastewater is economically viable and practically feasible if careful selection of process is conducted through selective research.
\end{abstract}

(c) 2014 Elsevier Ltd. All rights reserved.

\section{Introduction}

Textile industry consumes immense amounts of process water and chemicals. Approximately $21-377 \mathrm{~m}^{3}$ of water is consumed for one ton of textile product (Sahunin et al., 2006) and chemical consumption normally varies from $10 \%$ to over $100 \%$ of the weigh of the cloth (Ozturk et al., 2009). Estimates indicate that approximately, $7 \times 10^{5}$ tons of dyestuffs are produced annually and 280,000 tons of the textile dyes are discharged into water sinks through textile effluents (Eren, 2012; Jin et al., 2007). That, explains why textile effluent is characterized by high COD $(150-10,000 \mathrm{mg} /$ L), BOD (100-4000 mg/L), pH (6-10) and color content (50-2500) (Kalra et al., 2011). Moreover, discharge of even a small quantity (ca. $1 \mathrm{mg} / \mathrm{L}$ ) of dye is not acceptable and may produce toxic compounds at the end of treatment process (Ghodbane and Hamdaoui, 2009).

Since dyes are designed to resist degradation, these are chemically stable, non-biodegradable and exist as substances that possess

\footnotetext{
* Corresponding author. Tel.: +60 3 79674615; fax: +60 379675319 .
}

E-mail addresses: chem.uet@hotmail.com (A. Asghar), azizraman@um.edu.my, rshazrin@gmail.com (A.A. Abdul Raman), ashri@um.edu.my (W.M.A. Wan Daud). toxic and carcinogenic characteristics (Turhan et al., 2012). Therefore, a proper treatment strategy is required to meet the pollution control requirements. Majority of the conventional treatment methods comprise of adsorption (Yeh et al., 2002), coagulation (Alinsafi et al., 2005), filtration (Métivier-Pignon et al., 2003) and biological treatment (Paprowicz and Słodczyk, 1988). These methods are less efficient because dyes are stable against biological degradation (Wu et al., 2008), which results in sludge formation, membrane fouling and incomplete mineralization (Yeh et al., 2002; Alinsafi et al., 2005; Liu et al., 2007a,b).

Advanced Oxidation Processes (AOPs) comprise a series of methods including ozonation, photocatalysis, electrochemical oxidation, Fenton and Fenton-like processes. Although these processes use different reacting systems, all are characterized by similar chemical feature of utilizing highly reactive oxidizing agent such as hydroxyl radical ( $\mathrm{HO}^{\circ}$ ) with redox potential of $2.80 \mathrm{eV}$ (Krishnakumar and Swaminathan, 2011). However, the process that has gained attention is Fenton process because of rapid formation of $\mathrm{HO}$ radicals in acidic medium according to the following chemical reaction:

$\mathrm{Fe}^{2+}+\mathrm{H}_{2} \mathrm{O}_{2} \rightarrow \mathrm{Fe}^{3+}+\mathrm{HO}^{-}+\mathrm{HO}^{-}$ 
Technical feasibility study of Fenton oxidation together with other AOPs has been discussed in detail (Chong et al., 2012). Nevertheless, there are various factors that hinder the efficacy of the process such as reaction parameters (Tosik, 2005), types of salt used (Ledakowicz et al., 2000), high cost of hydrogen peroxide $\left(\mathrm{H}_{2} \mathrm{O}_{2}\right)$ and excess consumption of chemicals exclusively $\mathrm{H}_{2} \mathrm{O}_{2}$ (Hassan et al., 2012). Additionally, hazards associated with the transport, handling and storage of bulk quantities of $\mathrm{H}_{2} \mathrm{O}_{2}$ have made the process unsafe and economically challenging (Sheriff et al., 2007). It was also evident from the study conducted by Meric et al. (2004) in which the authors reported that $400 \mathrm{mg} / \mathrm{L}$ $\mathrm{H}_{2} \mathrm{O}_{2}$ and $100 \mathrm{mg} / \mathrm{L}$ iron salt were consumed for degrading $100 \mathrm{mg} /$ $\mathrm{L}$ of synthetic dye. Similarly, Argun and Karastas (2011) used $2000 \mathrm{mg} / \mathrm{L}$ of $\mathrm{H}_{2} \mathrm{O}_{2}$ for degrading $200 \mathrm{mg} / \mathrm{L}$ of synthetic dye. High consumption of $\mathrm{H}_{2} \mathrm{O}_{2}$ is not economically viable and it intensifies the need to find some cost effective and technically feasible alternatives for textile wastewater treatment.

One such option is in-situ production of $\mathrm{H}_{2} \mathrm{O}_{2} / \mathrm{HO}$ or some other oxidants with redox potential comparable to $\mathrm{HO}$. In this context, several research groups have reported in-situ production of $\mathrm{H}_{2} \mathrm{O}_{2}$ / HO (Tosik, 2005; Yang et al., 2010) and some other oxidants such as sulfate radicals $\left(\mathrm{SO}_{4}^{-}\right)$, permanganate $\left(\mathrm{MnO}_{4}^{-}\right)$, hypochlorite $\left(\mathrm{ClO}^{-}\right)$, chlorine dioxide $\left(\mathrm{ClO}_{2}\right)$ and ozone $\left(\mathrm{O}_{3}\right)$ for textile wastewater treatment (Anipsitakis and Dionysiou, 2003; Xu et al., 2005; Méndez-Díaz et al., 2009; Turhan et al., 2012). Out of all these oxidants, in-situ production of $\mathrm{H}_{2} \mathrm{O}_{2} / \mathrm{HO}^{\circ}$ has received much attention because of its high redox potential and non-selective nature for most of the organic contaminants (Neyens and Baeyens, 2003). The redox potential of few oxidizing agents is provided in Table 1. Possible methods that are available in literature for in-situ production of $\mathrm{H}_{2} \mathrm{O}_{2} / \mathrm{HO}$ include AOPs such as ozonation, photocatalysis, electrochemical oxidation and microbial fuel cells. Therefore, this review aims at discussing literature relevant to insitu $\mathrm{H}_{2} \mathrm{O}_{2} / \mathrm{HO}$ production by AOPs. However, there are some economical, technological and operational issues with commercial production of $\mathrm{H}_{2} \mathrm{O}_{2}$ that must be considered before going into the detail of in-situ production of $\mathrm{H}_{2} \mathrm{O}_{2} / \mathrm{HO}$.

\subsection{Challenges with commercially available $\mathrm{H}_{2} \mathrm{O}_{2}$}

Hydroxyl radical $\left(\mathrm{HO}^{\circ}\right)$ is unstable in nature that is why for wastewater treatment applications commercially available $\mathrm{H}_{2} \mathrm{O}_{2}$ is used as a source of $\mathrm{HO}^{\circ}$ production. It is one of the cleanest and ideal oxidants for the degradation of dyes and organic contaminants present in wastewater (Sheriff et al., 2007). Globally, demand for $\mathrm{H}_{2} \mathrm{O}_{2}$ has increased. According to the statistical report published by ICON Group, $\mathrm{H}_{2} \mathrm{O}_{2}$ with the total worth of US\$383,067 (Parker,

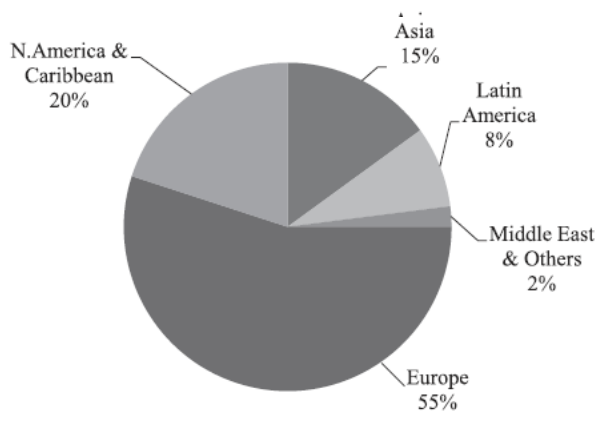

Fig. 1. World supplies of Exported Hydrogen Peroxide (2005).

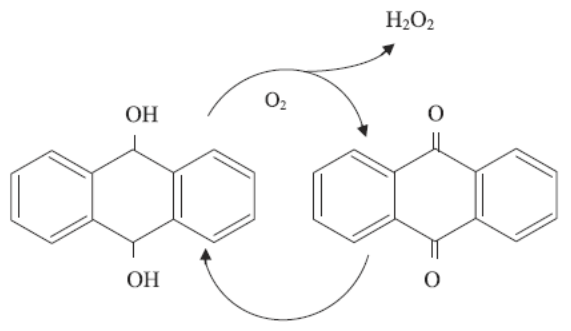

$\mathrm{H}_{2}$

Fig. 2. Conventional method for $\mathrm{H}_{2} \mathrm{O}_{2}$ production (Campos-Martin et al., 2006).

2004) was exported in 2005 which was increased by $37 \%$ in 2011(Parker, 2010). This group also discussed the breakdown of market in context of its supply and consumption in different regions of the world as shown in Fig. 1.

Besides increase in demand, the cost of commercially available $\mathrm{H}_{2} \mathrm{O}_{2}$ is also high. Industrial grade $\mathrm{H}_{2} \mathrm{O}_{2}$ costs $\$ 390-500$ per ton (Zhu and Logan, 2013). Commercially, $\mathrm{H}_{2} \mathrm{O}_{2}$ is produced by the oxidation of anthrahydroquinone as shown in Fig. 2. Successive developments in this technology have reduced the cost of chemicals by replacing conventional Raney-Ni by highly selective and highly active $\mathrm{Pd} / \mathrm{Al}_{2} \mathrm{O}_{3}$ (Chen, 2006). However, energy requirement of the process is still higher. This is because, for trade purposes, the product formed must be concentrated up to 70\% (Campos-Martin et al., 2006) which makes the process energy intensive and increase the cost of the product.

Direct method is another option where direct contact of hydrogen and oxygen over the surface of catalyst leads to the formation of $\mathrm{H}_{2} \mathrm{O}_{2}$. It is a simple process as oxygen and hydrogen are naturally available. But there are several problems that must be dealt with such as side reactions, decomposition of $\mathrm{H}_{2} \mathrm{O}_{2}$ over the surface of catalyst (Campos-Martin et al., 2006) and formation of explosive mixture from hydrogen and oxygen (Voloshin et al., 2007). Possible ways to overcome these limiting issues have also been proposed but their practical applications have not been realized (Voloshin et al., 2007; Lunsford, 2003).

Several authors have also studied the potential of other oxidizing agents such as $\mathrm{SO}_{4}^{--}, \mathrm{O}_{3}, \mathrm{MnO}_{4}^{-}$etc based on their redox potential as given in Table 1 . It is observed that most of the oxidizing agents have redox potential comparable to the $\mathrm{H}_{2} \mathrm{O}_{2}$ and $\mathrm{HO}$. Thus it is possible to use these oxidants for textile wastewater treatment. In order to confirm it, $\mathrm{Co}^{2+} / \mathrm{PMS}$ system as a source of $\mathrm{SO}_{4}^{--}$free radical was investigated for the degradation of Acid Red 88 (AR88) dye. In this study, it was found that $\mathrm{SO}_{4}^{--}$widens the $\mathrm{pH}$

Table 1

Redox potential of oxidizing agents.

\begin{tabular}{lll}
\hline Oxidizing agent & $\begin{array}{l}\text { Redox } \\
\text { potential }\end{array}$ & Reference \\
\hline Hydrogen peroxide $\left(\mathrm{H}_{2} \mathrm{O}_{2}\right)$ & 1.8 & $\begin{array}{l}\text { (Neyens and Baeyens, 2003; } \\
\text { Kelley et al., 2003) } \\
\text { (Kelley et al., 2003) }\end{array}$ \\
$\begin{array}{l}\text { Hydroxyl radicals }\left(\mathrm{HO}^{-}\right) \\
\text {Holes }\left(\mathrm{h}^{+} \text {) }\right.\end{array}$ & 2.8 & $\begin{array}{l}\text { (Fujishima et al., 2000) } \\
\text { (Kelley et al., 2003; Zhao }\end{array}$ \\
$\begin{array}{ll}\text { et al., 2010) } \\
\text { (Kelley et al., 2003) }\end{array}$ \\
$\begin{array}{l}\text { Ozone }\left(\mathrm{O}_{3}\right) \\
\text { Persulfate anions }\left(\mathrm{S}_{2} \mathrm{O}_{8}^{-2}\right)\end{array}$ & $2.53-3.1$ & $\begin{array}{l}\text { (Kelley et al., 2003; Liang } \\
\text { and Lee, 2008) } \\
\text { (Kelley et al., 2003) }\end{array}$ \\
Permanganate $\left(\mathrm{MnO}_{4}^{-}\right)$ & 2.01 & \\
\hline
\end{tabular}


range of the system but its selective nature for most of the oxidizing agents limit its application. Moreover, oxone which is used as a source of $\mathrm{SO}_{4}^{--}$is two times as costly as $\mathrm{H}_{2} \mathrm{O}_{2}$ (Anipsitakis and Dionysiou, 2003; Madhavan et al., 2009). Xu et al. (2005) examined decolorization efficiency of ten different dyes by utilizing $\mathrm{KMnO}_{4}$ and found that $\mathrm{MnO}_{4}^{-}$was efficient for decolorization and could be used as pre-treatment step for biological processes. However, concentration of $\mathrm{MnO}_{4}^{-}$and $\mathrm{pH}$ is important to control for achieving high decolorization efficiencies. In another study, Méndez-Díaz et al. (2009) collated the performance of conventional oxidizing agents $\left(\mathrm{ClO}^{-}, \mathrm{ClO}_{2}, \mathrm{KMnO}_{4}\right), \mathrm{O}_{3}, \mathrm{O}_{3} / \mathrm{H}_{2} \mathrm{O}_{2}, \mathrm{O}_{3} /$ activated carbon for the removal of sodium dodecylbenzenesulphonate (SDBS) and achieved $80 \%$ SDBS removal within 30 min with $\mathrm{O}_{3} / \mathrm{PAC}$ while others showed insignificant results.

It is suggested that conventional oxidizing agents are more suitable to perform decolorization than mineralization ( $\mathrm{Xu}$ et al. 2005). Limited works have been conducted on conventional oxidizing agents in this decade. Although, $\mathrm{SO}_{4}^{--}$has redox potential comparable to $\mathrm{HO}^{\circ}$ (Table 1), its selective nature for organic contaminants hinders its practical application. Therefore, it is concluded that $\mathrm{HO}^{\circ}$ is the most suitable option for textile or any other wastewater treatment. Therefore, this study was attempted to review and conclude all aspects of literature that determine the feasibility of in-situ production of $\mathrm{H}_{2} \mathrm{O}_{2} / \mathrm{HO}$ for textile wastewater treatment by using common AOPs.

\section{In-situ production of hydrogen peroxide/hydroxyl radical from AOPs}

In-situ production of $\mathrm{H}_{2} \mathrm{O}_{2} / \mathrm{HO}^{\circ}$ means its production at the time of treatment. From literature, possible methods that can be employed are AOPs comprising of iron catalyzed reaction, ozonation, photocatalysis, electrochemical or microbial fuel cells. Thus, this review is attempted to summarize AOPs studies that only focus on in-situ $\mathrm{H}_{2} \mathrm{O}_{2} / \mathrm{HO}$ production.

\subsection{Hydrogen substituted organic compounds as a source of $\mathrm{H}_{2} \mathrm{O}_{2}$}

The concept of hydrogen substituted organic compound for insitu $\mathrm{H}_{2} \mathrm{O}_{2}$ production has been suggested to overcome the shortcomings of direct method such as formation of explosive mixture of hydrogen and oxygen (Voloshin et al., 2007). Choudhary and Jan (2007) employed hydroxylamine as a source of hydrogen to react with oxygen to form $\mathrm{H}_{2} \mathrm{O}_{2}$ over $\mathrm{Pd} / \mathrm{Al}_{2} \mathrm{O}_{3}$ catalyst [Eq. (2) and (3)]

$2 \mathrm{NH}_{2} \mathrm{OH}+\mathrm{O}_{2} \rightarrow \mathrm{N}_{2}+2 \mathrm{H}_{2} \mathrm{O}+\mathrm{H}_{2} \mathrm{O}_{2}$

$2 \mathrm{NH}_{2} \mathrm{OH}+2 \mathrm{O}_{2} \rightarrow \mathrm{N}_{2}+3 \mathrm{H}_{2} \mathrm{O}_{2}$

This process was characterized by high reaction rates at neutra pH. However, net formation of $\mathrm{H}_{2} \mathrm{O}_{2}$ was decreased with increase in reaction time because of the decomposition of $\mathrm{H}_{2} \mathrm{O}_{2}$ over the surface of catalyst (Choudhary and Jana, 2007). However, $\mathrm{Br}^{-}$or $\mathrm{Cl}^{-}$ ions can possibly be used as inhibitors to suppress the decomposition of $\mathrm{H}_{2} \mathrm{O}_{2}$. But excess concentrations of $\mathrm{Cl}^{-}$ions act as scavengers for $\mathrm{HO}^{\circ}$ formed within the system (Ledakowicz et al., 2000). Park et al. (2000) discussed novel idea of catalyst loaded with organic compound for in-situ $\mathrm{H}_{2} \mathrm{O}_{2}$ production. They reported 1.5 times higher activity of zeolite beta supported Pd adsorbed with hydroquinone compared to zeolite beta supported with Pd alone

Yalfani et al. (2011) compared the performance of hydrazine, formic acid and hydroxylamine as hydrogen substitutes for $\mathrm{H}_{2} \mathrm{O}_{2}$ production. Among all, formic acid was observed to be the least efficient for $\mathrm{H}_{2} \mathrm{O}_{2}$ production. However, efficacy of the process was improved when $\mathrm{H}_{2} \mathrm{O}_{2}$ produced was utilized at the same time.
Moreover, hydrazine was found to be dependent on acidic conditions which cause the corrosion of catalyst. Furthermore, its decomposition over catalyst surface resulted in rapid formation of $\mathrm{H}_{2} \mathrm{O}_{2}$ which in turn decomposed rapidly rather than participating in oxidation process (Yalfani et al., 2011).

Since this method has been successfully applied for the treatment of organic contaminants; it can possibly be used for textile wastewater. Although, it can overcome the limitations encountered in direct method, incomplete conversion of organic compound may increase the toxicity of the treated textile wastewater. Also, there may be the reaction between organic compound and in-situ $\mathrm{HO}$ (conversion of in-situ $\mathrm{H}_{2} \mathrm{O}_{2}$ to $\mathrm{HO}^{\circ}$ in the presence of $\mathrm{Fe}^{2+}$ ) which lowers the process efficiency (Choudhary and Jana, 2007). Thus, it is suggested to use this process if organic compound (source of $\mathrm{H}_{2} \mathrm{O}_{2}$. is already present in the textile wastewater.

\subsection{Iron catalyzed $\mathrm{H}_{2} \mathrm{O}_{2}$ production}

Among transition metals, iron is known as a suitable catalyst for generation of $\mathrm{HO}^{\circ}$ radicals through Fenton process (Anipsitakis and Dionysiou, 2004). Its role in in-situ production of $\mathrm{H}_{2} \mathrm{O}_{2} / \mathrm{HO}$ was explored in the last decade.

Borda et al. (2003) explored the catalytic ability of iron pyrite to produce $\mathrm{HO}$ radical. According to the study, water adsorbed on the catalyst surface dissociates on sulfur deficient sites and forms $\mathrm{HO}$ radical in oxygen free medium. Later, in 2012, Wang et al. (2012 extended the idea of Borda and his co-workers for in-situ production of $\mathrm{HO}^{\circ}$ radicals. The report suggested that in the presence of oxygen, pyrite was thermodynamically unstable and either dissolved oxygen or $\mathrm{Fe}^{2+}$ ions was available in suspension for the production of oxidizing agents as shown in Fig. 3. Moreover, $\mathrm{Fe}^{2+}$ ions formed Fenton reagent system with $\mathrm{H}_{2} \mathrm{O}_{2}$ for degradation of organic contaminants (Wang et al., 2012). In both studies, it was found that production of sulfate ions $\mathrm{SO}_{4}^{2-}$ is an inevitable phenomenon and it may affect the yield of $\mathrm{HO}$ radicals by scavenging process (Liu et al., 2012).

Fang et al. (2013) exploited the reductive property of magnetic nano-particles for transformation of oxygen into $\mathrm{H}_{2} \mathrm{O}_{2}$. Here, transformation of oxygen into $\mathrm{H}_{2} \mathrm{O}_{2}$ takes place in two consecutive single electron transfers steps from MNPs sorbed $\mathrm{Fe}^{2+}$ with subsequent protonation with $\mathrm{H}^{+}$. Then $\mathrm{H}_{2} \mathrm{O}_{2}$ reacts with dissolved $\mathrm{Fe}^{2+}$ in bulk medium to produce $\mathrm{HO}$ radical through Fenton reaction. From reaction mechanism, it was observed that $\mathrm{pH}$ has a profound effect on the type of oxidizing species available in reaction medium. As shown in Fig. 4, superoxide radical $\left(\mathrm{O}_{2}^{--}\right)$is dominant at alkaline $\mathrm{pH}$ while $\mathrm{HO}^{\circ}$ is dominant at acidic condition.

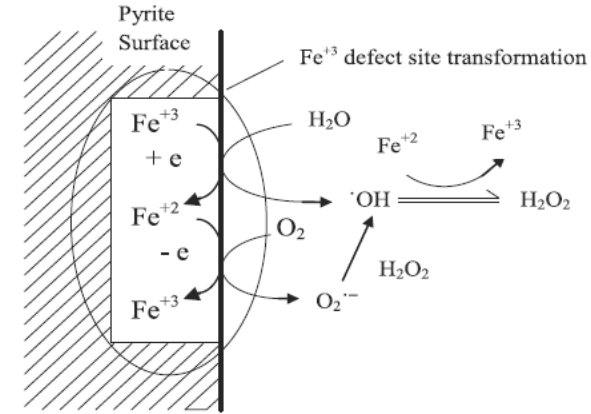

Fig. 3. In-situ production of $\mathrm{H}_{2} \mathrm{O}_{2} / \mathrm{HO}$ by iron pyrite (Wang et al., 2012 


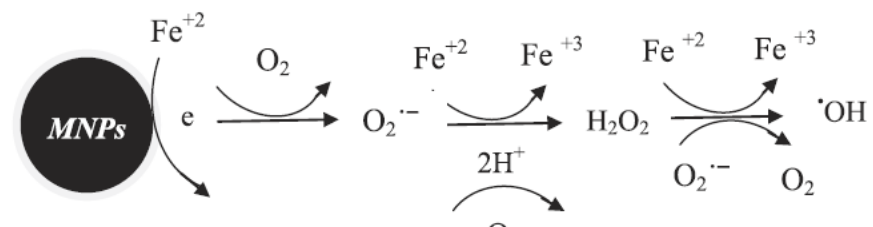

$\mathrm{O}_{2}$

Fig. 4. Reaction pathways for in-situ production of $\mathrm{HO} / \mathrm{H}_{2} \mathrm{O}_{2}$ utilizing MNPs (Fang et al., 2013).

Although the application of above mentioned processes has not yet been investigated for textile wastewater treatment, comparison of these techniques with conventional Fenton oxidation processes portrays the feasibility of these methods for textile wastewater treatment.

Besides, zero valent iron $\left(\mathrm{Fe}^{0}\right)$ has potential for in-situ generation of $\mathrm{H}_{2} \mathrm{O}_{2}$. Degradation phenomenon by $\mathrm{Fe}^{0}$ is attributed to the direct transfer of electron from metal surface to the dye or organic contaminant prior to in-situ production of $\mathrm{H}_{2} \mathrm{O}_{2}$, (Cao et al., 1999). This degradation step takes place via oxidizing agents such as $\mathrm{H}_{2} \mathrm{O}_{2}$ and other oxidative species depending on $\mathrm{pH}$ in oxic condition which in turn produce $\mathrm{HO}^{\circ}$ radical for decolorization of dyes through Fenton process [Eq. (4) and (5)] (Yang et al., 2010).

$\mathrm{Fe}^{0}+\mathrm{O}_{2}+2 \mathrm{H}^{+} \rightarrow \mathrm{H}_{2} \mathrm{O}_{2}+\mathrm{Fe}^{2+}$

$\mathrm{Fe}^{3+}+\mathrm{Fe}^{0} \rightarrow \mathrm{Fe}^{2+}$

Wang et al. (2010) reported that under oxic conditions, high COD removal was obtained because of the combined effect of oxidation and adsorption of dyes on iron hydroxides, generated from $\mathrm{Fe}^{0}$ oxidation. From above mentioned reaction equations, it can be inferred that the efficacy of $\mathrm{Fe}^{\hat{0}}$ depends on the transfer of electron from the iron surface to the targeted contaminants. Lee et al. (2007) investigated the oxidation of $\mathrm{Fe}^{0}$ accelerated by peroxometalate (POM) as electron shuttle to improve the catalytic performance of the $\mathrm{Fe}^{0}$. POM is not suitable for the degradation of dyes waste; however quinone intermediates can possibly be used to accelerate the transfer of electrons.

Among aforementioned alternatives, iron catalyzed production of in-situ $\mathrm{H}_{2} \mathrm{O}_{2} / \mathrm{HO}$ is a viable option for textile wastewater treatment. Moreover, it has some advantages over hydrogen substituted organic compound as there may be incomplete conversion of organic compound in later option, no matter produced $\mathrm{H}_{2} \mathrm{O}_{2}$ is utilized in-situ or ex-situ. Furthermore, iron catalyzed in-situ production of $\mathrm{H}_{2} \mathrm{O}_{2} / \mathrm{HO}$ is also cost effective because single catalyst can be used for oxidant production as well as for degradation of dyes in textile wastewater. As evident from one study, the operating cost for Remazol Brilliant blue R (RBBR) degradation by $\mathrm{Fe}^{0} / \mathrm{air}$ reduced from $0.015 \mathrm{US} \$ \mathrm{~g}$ of dye (Fenton process) to $0.00113 \mathrm{US} \$ \mathrm{~g}$ of dye (Chang et al. 2009).

\subsection{Ozonation for in-situ $\mathrm{H}_{2} \mathrm{O}_{2} / \mathrm{HO}$ production}

Ozonation is an environmentally sound technique because of no sludge formation; potential to perform decolorization and degradation in a single step; decomposition of residual ozone into water and oxygen; less space requirement for equipment installation; less hazardous as no stock of $\mathrm{H}_{2} \mathrm{O}_{2}$ is required for the oxidation step and ease of operation (Chu and Ma, 2000; Oguz et al., 2005). Therefore, it is recommended to consider it an efficient option for in-situ production of $\mathrm{H}_{2} \mathrm{O}_{2} / \mathrm{HO}$ for dye degradation.
Ozonation is suitable for complete decolorization rather than mineralization (Tosik, 2005). Ozonation process follows two different routes for degradation of textile dyes based on $\mathrm{pH}$ value. Under acidic conditions, ozone selectively attacks the aromatic and conjugated double bonds of chromophores in dye structures (Turhan et al., 2012) and leads to the formation of aldehydes, carboxylic acids and other by-products (Nawrocki and KasprzykHordern, 2010)

However, at high $\mathrm{pH}$ values, ozonation mechanism changes from direct ozonation to complex chain mechanism. As a result, $\mathrm{HO}, \mathrm{HO}_{2}$ and $\mathrm{HO}_{4}$ radicals are formed (Glaze et al., 1987). Among these, $\mathrm{HO}^{-}$is dominant and it has a potential to open aromatic rings of dye present in textile wastewater (Chu and Ma, 2000). It was also explained by the findings of Turhan et al. (2012) that the reported COD removal of direct dye stuff in wastewater at $\mathrm{pH} 6.5$ was $23.33 \%$ after $2 \mathrm{~h}$ of ozone bubbling which increased to $64.96 \%$ when $\mathrm{pH}$ value increased to 12 .

Moreover, $\mathrm{pH}$ also effects the time required for complete decolorization. For example, time required for decolorizing direct dye stuff reduced to $59.62 \%$ when $\mathrm{pH}$ increased from 2 to 12 (Turhan et al., 2012). In another experimental study by Muthukumar et al. (2004), it was reported that the time required for complete decolorization of Acid Red 88 (AR88) by ozonation increased till $\mathrm{pH} 7$ and then decreased which clearly indicates the decomposition of $\mathrm{O}_{3}$ into $\mathrm{HO}$. The $\mathrm{COD}$ value obtained as a result of regression analysis at alkaline $\mathrm{pH}$ was $64 \%$ according to the study done by Muthukumar et al. (2004).

From this review, it can therefore be concluded that $\mathrm{pH}$ is the key parameter for accelerating in-situ production of $\mathrm{HO}^{\circ}$. Few investigations have discussed analogous results. For example, de Souza et al. (2010) and Tehrani-Bagha et al. (2010) reported slight change in dye degradation efficiencies at high $\mathrm{pH}$ values as compared to acidic conditions. They supported this result by argumenting that it was buffered or non-buffered solution that played a role in promoting in-situ $\mathrm{HO}$ production at high $\mathrm{pH}$ values. They explained that in non-buffered solution, $\mathrm{pH}$ value decreased because of the formation of acidic products and left no effects at the end. To overcome this problem, catalytic ozonation is an efficient alternative because ozone can decompose itself to produce $\mathrm{HO}^{\circ}$ in the presence of catalyst. Furthermore, use of catalyst also promotes controlled decomposition of ozone into $\mathrm{HO}^{\circ}$ resulting in effective mineralization of dye and organic contaminants (Nawrocki and Kasprzyk-Hordern, 2010; Kasprzyk-Hordern et al., 2003).

Wu et al. (2008) compared catalytic ozonation for homogeneous $(\mathrm{Mn}(\mathrm{II}))$ and heterogeneous $\left(\mathrm{UV} / \mathrm{TiO}_{2} \& \mathrm{MnO}_{2}\right.$ ) catalytic system for degradation of Reactive Red 2 (RR2) with subsequent mechanisms. And they observed high degradation of RR2 as a result of radial chain reaction and surface mechanism.

Performance of catalytic ozonation can further be improved in the presence of activated carbon as it enhances the chances of insitu HO radical formation. For this, Faria et al. (2009) demonstrated the activity of composite ACo-Ce-O for ozonation of one acid and 
Table 2

Application of AOPs for in-situ production of $\mathrm{H}_{2} \mathrm{O}_{2} / \mathrm{HO}$ for textile wastewater treatment.

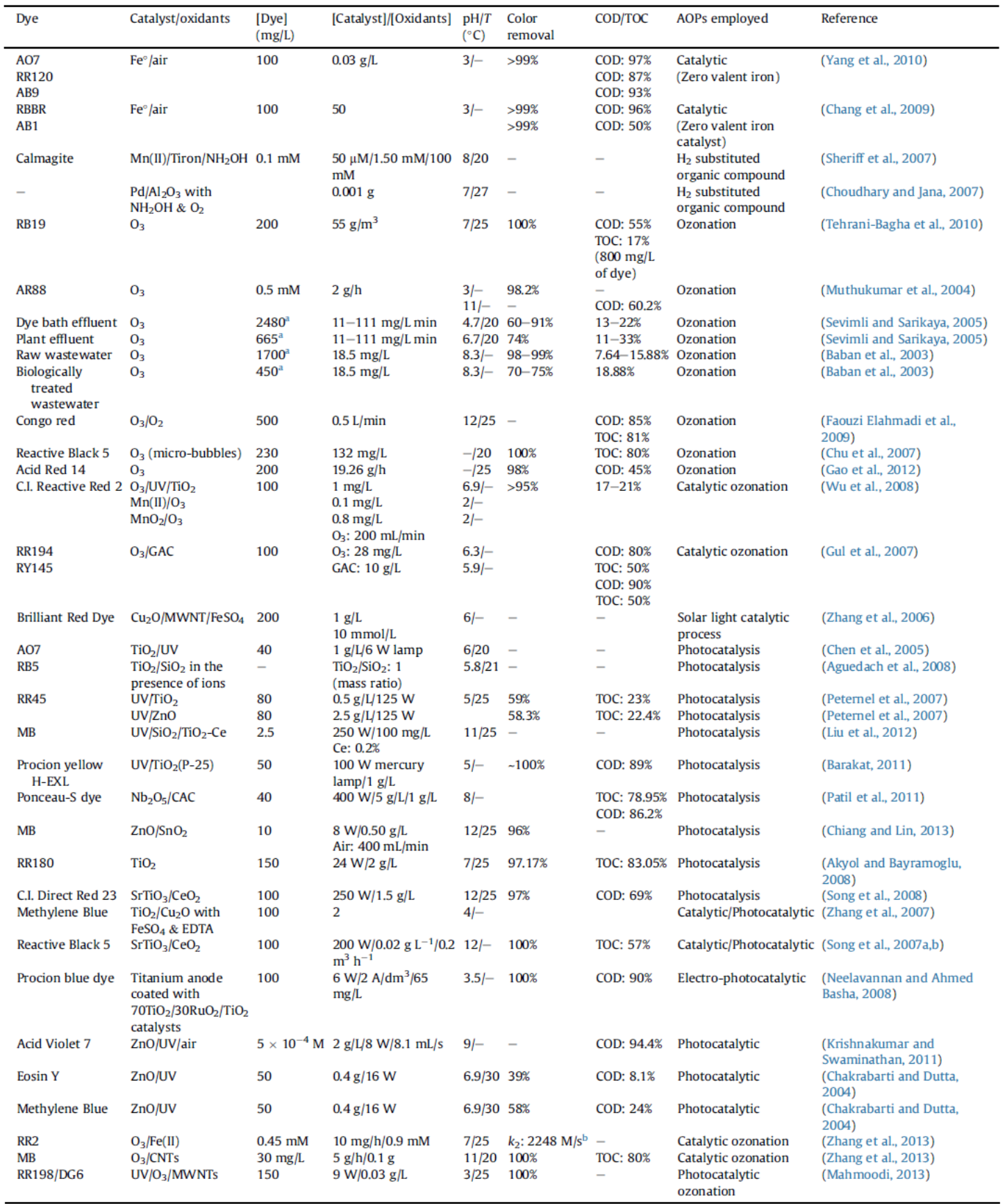

AO7: Acid Orange 7; RR120: Reactive Red 120; AB9: Acid blue 9; RBBR: L.C Remazol Brilliant Blue; AB1: C.I. Acid Black 1; RB19: C.I. Reactive 19; AR88: Acid Red 88; RR2: C.I. Reactive Red 2 ; CR: Congo Red; RR194: C.I. Reactive Red 194; RR145: C.I. Reactive Red 145; AO7: Acid Orange 7; RB5: Reactive Black 5; RR45: C.I. Reactive Red 45; MB: Methylene Blue; RR180: Remazol red F-3B; R23: C.I. Direct Red 23; 4BS: C.I. Direct Red 23; AV7: Acid Violet 7; RR2: Reactive Red 2; MB: Methylene Blue; RR198: Reactive red 198; DG: Direct Green.

a Concentration of real wastewater is always reported in terms of COD value.

b Rate constant.

\section{Link to Full-Text Articles :}

